\title{
Growth Response of Oreochromis niloticus ( $L$ ) fed Crude Extract of Azadirachta indica Saponins
}

\author{
I. O. Obaroh ${ }^{1}$, G. C. Nzeh ${ }^{2}$, S. O. Oguntoye ${ }^{3}$ and D. Y. Bawa ${ }^{4}$ \\ ${ }^{1}$ Department of Biological Sciences kebbi State University of Science and Technology, P.M.B 1144 Aliero, \\ Kebbi State, Nigeria. \\ ${ }^{2}$ Department of Biological Sciences University of Ilorin, Ilorin, Nigeria. \\ ${ }^{3}$ Department of Industrial Chemistry University of Ilorin, Ilorin, Nigeria. \\ ${ }^{4}$ Department of Forestry and Fisheries, kebbi State University of Science and Technology, P.M.B 1144 Aliero, \\ Kebbi State, Nigeria
}

\begin{abstract}
A 56 day feeding experiment was carried out to investigate the effects of Azadirachta indica saponins on growth of Oreochromis niloticus. Saponins from Azadirachta indica leaf was isolated and incorporated into a basal diet at $0.0,0.5,1.0,2.0,4.0$ and $8.0 \mathrm{~g} \mathrm{~kg}^{-1}$ respectively (representing; D1, D2, D3, D4, D5 and D5), and fed to 180 Oreochromis niloticus of Mean $\pm S D$ weight 20.97 $\pm 3.52-23.13 \pm 1.99 \mathrm{~g}$, twice daily at $3 \%$ of their body weight. There was variations $(p<0.05)$ in the growth parameters, the highest Mean $\pm S D$ weight gain of $23.12 \pm 2.79 \mathrm{~g}$ was observed in group $D 3\left(1.0 \mathrm{~g} \mathrm{~kg}^{-1}\right.$ diet $)$ which also had the best average daily growth rate, specific growth rate and food conversion ratio of $0.44 \pm 0.01,1.158 \pm 0.02$ and $1.57 \pm 1.09$ respectively. Gradual increase in weight gain was observed as the concentration of A. indica saponins increased from 0.5 $1.0 \mathrm{~g} \mathrm{~kg}^{-1}$ and a decrease was observed from $2.0-8.0 \mathrm{~g} \mathrm{~kg}^{-1}$ diet. The control group had the least percentage weight gain of $68.37 \pm 2.99 \%$. This study infers that for efficient and sustainable development in tilapia culture Azadirachta indica saponins could be used to enhance growth of Oreochromis niloticus.
\end{abstract}

Key words: Concentrations, extract, growth, phyto-additives, saponins.

\section{Introduction}

The growing tendency for food safety has led to the ban of antibiotics which has widely been used to enhanced growth, to replace their effect there is need to search for natural alternatives. Phyto-additives are folder additive obtained from plant extract. Plant materials serve as storehouses for safer, cheaper and biodegradable chemicals. [1] reported that hormones, antibiotics, vitamins and several other chemicals have been tested as growth promoters, antibacterials and other purposes in mariculture, though they have been reported to have positive effects on fish and shrimps it has been observed that they cannot be recommended in commercial culture operations due to their residual effects in the muscles of fish and shrimps.

Saponins are naturally occurring surface - active glycosides with a distinct foaming characteristic. It is an important group of plant metabolites [2]. Saponins have been variously attributed with a diverse range of properties some of which include both beneficiary and detrimental effects [3]. Saponin-rich plant extract (Yucca schidigera) have been found to improve growth, feed efficiency and health in ruminant animals [4]. [5] also observed that the supplementation of feed with leaves of Sebania sesban, known for its high saponin content have the potential of improving protein flow from the rumen. Azadirachta indica is a fast-growing tree that can reach a height of $15-20 \mathrm{~m}$, usually evergreen tree, with a fairly dense crown and a globrous leaves divided into leaflets. The opposite pinnate leaves are $20-40 \mathrm{~cm}$ long, the terminal leaflet is often missing, the petioles are short. Very young leaves are reddish to purplish in colour, the shape of mature leaflets is more or less asymmetric and their margins are dentate with the exception of the base of their basiscopal half, which is normally very strongly reduced and cuneate or wedge-shaped [6].

Oreochromis niloticus can be recognized at a glance by the characteristics pattern of dark and light bands crossing the caudal fin. The body is rather elongate and usually shows a number of narrow bands on the back. It is one of the largest tilapia reaching the considerable length of about $50 \mathrm{~cm}$ [7]. The effects of Azadirachta indica leaf at controlling reproduction had been reported in fish and rats [8 \& 9]. Thus the aim of this work was to study the effects of Azadirachta indica saponins on the growth of Oreochromis niloticus.

\subsection{Experimental site}

\section{Materials and Methods}

This study was carried at Kwara state Ministry of Agriculture and Natural Resources hatchery farm Ilorin, Kwara state, Nigeria. Ilorin is the state capital of Kwara state located in north western Nigeria on latitude $08^{\circ} 30^{\prime} \mathrm{N}$ and longitude $04^{\circ} 35^{\prime} \mathrm{E}$. 


\subsection{Identification and Preparation of Plant Materials.}

Azadirachta indica fresh leaf were collected within University of Ilorin Campus, they were authenticated at the herbarium section of Department of Plant Biology University of Ilorin, Nigeria before use. The fresh leaf was shade dried for 2 weeks, before grinding into fine powder using an electric blender. The crude ethanol extract was prepared by soaking $100 \mathrm{~g}$ of dried powdered sample in $500 \mathrm{ml}$ of ethanol for 24 hours. The filtrate was concentrated to semi solid substance.

\subsection{Isolation of Saponins}

Saponins content of the leaf crude extract was isolated according to the methods of [10] and as modified by [11]. $100 \mathrm{ml}$ of diethyl ether was measured and mixed with the crude extract, the mixture was stirred very well and then poured into a separating funnel, the mixture in the separating funnel was further shaken severally and allowed to settled down, after a while two layers were formed the bottom layer which contain the saponins was separated from the top layer, it was further washed several time with diethyl ether until when the solvent was cleared of pigments. $4 \mathrm{~g}$ of $\mathrm{NaCl}$ and $100 \mathrm{ml}$ of Iso-propanol was added to the Saponins content in the separating funnel shaken vigorously and then allowed to settle down, after a while two layers were further formed the top layer containing the crude saponins was separated from the bottom layer. The crude saponin was further rinsed with $5 \mathrm{~g}$ of $\mathrm{NaCl}$ and $100 \mathrm{ml}$ of distilled water before it was concentrated in a water bath to obtained a jelly-like substance.

\subsection{Preparation of Experimental Diets}

The feedstuffs were obtained locally from the market. Basal feed was formulated to provide $35 \%$ crude protein as shown in Table 1. Azadirachta indica saponins extract was added to the basal diet at 0.5, 1.0, $2.0,4.0$ and $8.0 \mathrm{~g} \mathrm{~kg}^{-1}$ diet respectively. The feedstuff were thoroughly mixed in a pelleting/mixing machine, hot water was added at intervals to gelatinized the starch, feeds were pelletized using $2 \mathrm{~mm}$ diameter die, air dried and each packed in a labelled polythene bag and stored in the refrigerator till when needed. The proximate compositions of the experimental diets were analyzed using [12] method of analysis.

\subsection{Experimental Design}

One hundred and eighty Oreochromis niloticus of mean \pm SD weight $20.97 \pm 3.52-23.13 \pm 1.99$ g were obtained from Kwara state Ministry of Agriculture and Natural Resources Hatchery Farm Ilorin, Kwara state, Nigeria. Fishes were acclimatized for one week, after acclimatization they were divided into six groups D1, D2, D3, D4, D5 and D6 respectively (also representing the six experimental diets with D1 serving as the control group) each group was replicated three times, each replicate consist of 10 fishes, these were stocked in outdoor concrete tanks $(2 \times 2 \times 1.25 \mathrm{~m})$ supplied with 450 litres of water. Fish were fed $3 \%$ of their body weight/day with the diets at two instalments between 0900-0930 and 1700-1730 for 56 days. Tanks were drained and washed twice a week and replenished with fresh water. Water parameter which include dissolved oxygen, $\mathrm{pH}$ and temperature were monitored biweekly.

\subsection{Statistical Analysis}

All data were analyzed using one-way ANOVA as contained in the SPSS 18.

\subsection{Proximate Composition of Experimental Diet}

\section{Results}

Table 1 shows the ingredients and proximate composition of the experimental diet, the inclusion of crude extract of Azadirachta indica saponins at different concentrations showed little or no alteration in the percentage crude protein requirement for tilapia culture.

\subsection{Mean Weight Gain}

The highest mean weight gain $(23.12 \pm 2.79 \mathrm{~g})$ was observed in group fed $1.0 \mathrm{~g} \mathrm{~kg}^{-1}$ diet (D3) while the lowest mean weight gain $(14.68 \pm 3.88 \mathrm{~g})$ was observed in the control group (D1). Statistical analysis of the mean weight gain showed significant difference $(\mathrm{p} \leq 0.05)$ when the highest mean weight gain was compared with the lowest mean weight gain. There was also significant difference $(\mathrm{p} \leq 0.05)$ when the lowest mean value observed in the control group was compared with the mean value of the group fed the highest concentration of the plant extract (D6), but no significant difference ( $\mathrm{p} \geq 0.05)$ when group D2 was compared with groups; D4 and D5 as shown in Table 2.

\subsection{Percentage Weight Gain}

The highest percentage weight gain $(91.31 \pm 3.64 \%)$ was observed in group fed $1.0 \mathrm{~g} \mathrm{~kg}^{-1} \operatorname{diet}(\mathrm{D} 3)$ while the lowest percentage weight gain $(68.37 \pm 2.99 \%)$ was observed in the control group (D1). Analysis of 
variance showed significant difference $(p \leq 0.05)$ when the highest mean value was compared with the lowest mean value and with all other percentage mean weight values in the groups, but no significant difference $(\mathrm{p} \geq$ 0.05 ) when group fed $0.5 \mathrm{~g} \mathrm{~kg}^{-1}$ diet (D2) was compared with group fed $4.0 \mathrm{~g} \mathrm{~kg}^{-1}$ diet (D5) as shown in Table 2 .

\subsection{Average Daily Growth (ADG)}

The highest daily growth rate $(0.445 \pm 0.01)$ was observed in group fed $1.0 \mathrm{~g} \mathrm{~kg}^{-1}$ diet (D3) while the lowest daily growth rate $(0.292 \pm 0.03)$ was observed in the control group. Statistical analysis showed significant difference $(\mathrm{p} \leq 0.05)$ when the highest mean value was compared with the lowest mean value. There was no significant difference $(\mathrm{p} \geq 0.05)$ when the group fed $0.5 \mathrm{~g} \mathrm{~kg}^{-1}$ diet (D2) was compared with groups fed 2.0 and $4.0 \mathrm{~g} \mathrm{~kg}^{-1}$ diet (D3 and D5) respectively (Table 2).

\subsection{Specific Growth Rate (SGR)}

The highest specific growth rate (1.158 \pm 0.02$)$ was observed in group fed $1.0 \mathrm{~g} \mathrm{~kg}^{-1}$ diet (D3), while the lowest specific growth rate $(0.932 \pm 0.04)$ was observed in the control group (D1). Statistical analysis showed significant difference $(\mathrm{p} \leq 0.05)$ when the highest mean value observed in group D3 was compared with the lowest mean value observed in group D1. There was no significant difference $(p \geq 0.05)$ when group D2 was compared with group D5 as shown in Table 2.

\subsection{Protein Efficiency Ratio}

The highest PER $(0.691 \pm 0.03)$ was observed in the group fed $1.0 \mathrm{~g} \mathrm{~kg}^{-1}$ diet (D3) while the lowest PER $(0.458 \pm 0.02)$ was observed in the control group (D1). Analysis of variance showed significant difference $(\mathrm{p} \leq$ 0.05 ) when the highest mean value observed in group D3 was compared with the lowest mean value observed in the control group (D1) and when D3 was compared with all other values in the groups. There was no significant difference $(\mathrm{p} \geq 0.05)$ when the mean value observed in D2 was compared with the mean value observed in D6 (Table 2).

\subsection{Food Conversion Ratio}

The highest food conversion ratio (FCR) of $2.01 \pm 1.16$ was observed in the control group (D1) while the lowest FCR of $1.57 \pm 1.09$ was observed in the group fed $1.0 \mathrm{~g} \mathrm{~kg}^{-1}$ diet (D3). Analysis of variance showed significant difference $(\mathrm{p} \leq 0.05)$ when the highest mean value observed in the control group was compared with the lowest mean value observed in group D3. There was no significant difference when the lowest mean value observed in D3 was compared with the mean values of groups D2, D4 and D5 respectively, and no significant difference $(p \geq 0.05)$ when the value observed in the control group was compared with the mean value of group D6.

\subsection{Physico-chemical Parameters of water}

The dissolved oxygen, temperature and $\mathrm{pH}$ of tanks water used in culturing fish fed with crude extract of Azadirachta indica saponins were within the range of $5.37 \pm 0.09-5.80 \pm 0.27,26.33 \pm 0.58-27.50 \pm 0.50$ and $7.41 \pm 0.04-7.72 \pm 0.06$ respectively as shown in Table 3 . Statistical analysis of the dissolved oxygen and temperature showed no significant difference $(\mathrm{p} \geq 0.05)$ across all the groups, but there were variations in the $\mathrm{pH}$ value, a significant difference $(\mathrm{p} \leq 0.05)$ was observed when the $\mathrm{pH}$ value of the control group was compared with the $\mathrm{pH}$ values of groups; $\mathrm{B}, \mathrm{D}$ and $\mathrm{E}$ respectively, as shown in Table 3.

Table 1: Composition of Experimental Diet

\begin{tabular}{|c|c|c|c|c|c|c|}
\hline \multicolumn{7}{|c|}{ Groups } \\
\hline Ingredients (g) & $\overline{\text { D1 }}$ & $\overline{\mathbf{D 2}}$ & $\overline{\mathbf{D 3}}$ & $\overline{\mathrm{D4}}$ & D5 & $\overline{\text { D6 }}$ \\
\hline Fish meal & 30 & 30 & 30 & 30 & 30 & 30 \\
\hline Yellow Maize & 25 & 25 & 25 & 25 & 25 & 25 \\
\hline Soya meal & 20 & 20 & 20 & 20 & 20 & 20 \\
\hline Blood meal & 10 & 10 & 10 & 10 & 10 & 10 \\
\hline Groundnut cake & 08 & 08 & 08 & 08 & 08 & 08 \\
\hline Vit/Min premix & 03 & 03 & 03 & 03 & 03 & 03 \\
\hline Methionine & 02 & 02 & 02 & 02 & 02 & 02 \\
\hline Cassava starch & 02 & 02 & 02 & 02 & 02 & 02 \\
\hline Plant extract & 0.0 & 0.5 & 1.0 & 2.0 & 4.0 & 8.0 \\
\hline
\end{tabular}

Vitamin/mineral premix: Vitamin A, I.U.; Vitamin D, 11252U; Vitamin E, 71 U; Vitamin K3, 2mg; Vitamin B12, 0.015mg; Pantothenic acid 5mg; Nicotinic acid 14mg; Folic acid, 0.4mg; Biotin, 0.04mg; Choline, $150 \mathrm{mg}$; Cobalt 0.2mg; Copper, $4.5 \mathrm{mg}$; Iron, 21mg; Manganese, 20mg; Iodine, 0.6mg; Selenium, 2.2mg; Zinc, 20mg; 
Antioxidant, 2mg.

Table 2: Proximate Composition of Experimental Diet

\begin{tabular}{|c|c|c|c|c|c|c|}
\hline Parameters (\%) & D1 $\left(0.0 \mathrm{gkg}^{-1}\right)$ & D2 $\left(0.5 \mathbf{g k g}^{-1}\right)$ & $\begin{array}{c}\text { Groups } \\
\text { D3 }\left(1.0 \text { gkg }^{-1}\right)\end{array}$ & D4 $\left(2.0 \mathrm{gkg}^{-1}\right)$ & D5 $\left(4.0 \mathrm{gkg}^{-1}\right)$ & D6 $\left(8.0 \mathrm{gkg}^{-1}\right)$ \\
\hline Crude protein & $34.99 \pm 0.67$ & $35.01 \pm 0.25$ & $34.85 \pm 0.77$ & $35.16 \pm 0.19$ & $35.07 \pm 0.92$ & $35.34 \pm 0.33$ \\
\hline Crude fat & $14.31 \pm 0.59$ & $13.65 \pm 1.01$ & $14.28 \pm 0.88$ & $14.25 \pm 0.51$ & $14.22 \pm 0.83$ & $13.89 \pm 0.98$ \\
\hline Ash content & $15.09 \pm 1.05$ & $14.81 \pm 1.47$ & $14.90 \pm 1.72$ & $15.12 \pm 0.99$ & $14.93 \pm 0.86$ & $15.13 \pm 0.93$ \\
\hline Moisture & $09.32 \pm 1.06$ & $10.05 \pm 0.79$ & $09.66 \pm 0.44$ & $10.44 \pm 0.27$ & $09.54 \pm 0.69$ & $10.19 \pm 0.38$ \\
\hline
\end{tabular}

$\mathrm{n}=3$. All parameters within the same group showed no significant difference $(\mathrm{p} \geq 0.05)$.

Table 3: Growth Parameters and Nutrient Utilization of O. niloticus fed Crude Extract of Azadirachta indica Saponins

\begin{tabular}{|c|c|c|c|c|c|c|}
\hline Parameters & $\begin{array}{c}\text { D1 } \\
\left(\mathbf{0 . 0} \mathbf{~ g k g}^{-1}\right)\end{array}$ & $\begin{array}{c}\text { D2 } \\
\left(0.5 \mathrm{gkg}^{-1}\right)\end{array}$ & $\begin{array}{c}\text { D3 } \\
\left(1.0 \mathrm{gkg}^{-1}\right)\end{array}$ & $\begin{array}{c}\text { D4 } \\
\left(2.0 \mathrm{gkg}^{-1}\right)\end{array}$ & $\begin{array}{c}\text { D5 } \\
\left(4.0 \mathrm{gkg}^{-1}\right)\end{array}$ & $\begin{array}{c}\text { D6 } \\
\left(8.0 \mathrm{gkg}^{-1}\right)\end{array}$ \\
\hline Mean initial weight (g) & $21.47 \pm 3.21$ & $22.42 \pm 2.64$ & $23.13 \pm 1.99$ & $22.47 \pm 3.03$ & $21.63 \pm 2.67$ & $20.97 \pm 3.52$ \\
\hline Mean final weight (g) & $36.15 \pm 2.10^{\mathrm{a}}$ & $41.44 \pm 4.25^{\mathrm{bc}}$ & $44.25 \pm 3.68^{\mathrm{d}}$ & $42.36 \pm 2.99^{\mathrm{cd}}$ & $39.84 \pm 3.78^{b}$ & $37.41 \pm 4.17^{\mathrm{a}}$ \\
\hline Mean weight gain $(\mathrm{g})$ & $14.68 \pm 3.88^{a}$ & $19.02 \pm 3.65^{\mathrm{c}}$ & $23.12 \pm 2.79^{d}$ & $19.87 \pm 3.19^{c}$ & $18.21 \pm 4.18^{\mathrm{c}}$ & $16.44 \pm 2.88^{\mathrm{b}}$ \\
\hline$\%$ weight gain & $68.37 \pm 2.99^{a}$ & $84.83 \pm 4.17^{\mathrm{c}}$ & $91.31 \pm 3.64^{\mathrm{e}}$ & $88.35 \pm 3.62^{\mathrm{d}}$ & $84.19 \pm 4.22^{\mathrm{c}}$ & $78.40 \pm 2.89^{b}$ \\
\hline $\mathrm{ADG}^{1}$ & $0.292 \pm 0.03^{\mathrm{a}}$ & $0.374 \pm 0.02^{\mathrm{cd}}$ & $0.445 \pm 0.01^{\mathrm{e}}$ & $0.384 \pm 0.02^{\mathrm{d}}$ & $0.357 \pm 0.03^{\mathrm{c}}$ & $0.335 \pm 0.04^{\mathrm{b}}$ \\
\hline $\mathrm{SGR}^{2}$ & $0.932 \pm 0.04^{\mathrm{a}}$ & $1.105 \pm 0.02^{\mathrm{c}}$ & $1.158 \pm 0.02^{\mathrm{e}}$ & $1.142 \pm 0.04^{\mathrm{d}}$ & $1.095 \pm 0.02^{\mathrm{c}}$ & $1.034 \pm 0.04^{\mathrm{b}}$ \\
\hline $\mathrm{PER}^{3}$ & $0.458 \pm 0.02^{\mathrm{a}}$ & $0.496 \pm 0.01^{\mathrm{b}}$ & $0.691 \pm 0.03^{\mathrm{e}}$ & $0.591 \pm 0.04^{\mathrm{d}}$ & $0.508 \pm 0.03^{\mathrm{c}}$ & $0.498 \pm .0 .02^{\mathrm{b}}$ \\
\hline $\mathrm{FCR}^{4}$ & $2.01 \pm 1.16^{\mathrm{d}}$ & $1.86 \pm 1.32^{\mathrm{bc}}$ & $1.57 \pm 1.09^{\mathrm{ab}}$ & $1.74 \pm 0.99^{\mathrm{c}}$ & $1.81 \pm 1.11^{\mathrm{bc}}$ & $1.91 \pm 0.94^{\mathrm{d}}$ \\
\hline
\end{tabular}

${ }^{1}$ Average Daily Growth. ${ }^{2}$ Specific Growth rate. ${ }^{3}$ Protein Efficiency Ratio. ${ }^{4}$ Food Conversion Ratio. $\mathrm{n}=3$. Different letter within the same row show significant difference at $\mathrm{p} \leq 0.05$.

Table 4: Dissolved oxygen, Temperature and pH of Tank Water Used to Culture O. niloticus Fed Crude Extract of Azadirachta indica Saponins

\begin{tabular}{|c|c|c|c|}
\hline \multicolumn{4}{|c|}{ Parameters } \\
\hline Groups/Concentration & Dissolved oxygen $(\mathrm{mg} / \mathrm{L})$ & Temperature $\left({ }^{\circ} \mathrm{C}\right)$ & pH \\
\hline D1 $\left(0.0 \mathrm{gkg}^{-1}\right)$ & $5.75 \pm 0.07^{\mathrm{a}}$ & $26.50 \pm 0.50^{\mathrm{a}}$ & $7.41 \pm 0.04^{\mathrm{a}}$ \\
\hline D2 $\left(0.5\right.$ gkg $\left.^{-1}\right)$ & $5.64 \pm 0.20^{\mathrm{a}}$ & $27.00 \pm 1.00^{\mathrm{a}}$ & $7.52 \pm 0.06^{\mathrm{abc}}$ \\
\hline D3 $\left(1.0 \mathrm{gkg}^{-1}\right)$ & $5.47 \pm 0.46^{\mathrm{a}}$ & $27.33 \pm 0.58^{\mathrm{a}}$ & $7.67 \pm 0.30^{\mathrm{cd}}$ \\
\hline D4 $2.0\left(\mathrm{gkg}^{-1}\right)$ & $5.50 \pm 0.15^{\mathrm{a}}$ & $26.33 \pm 0.58^{\mathrm{a}}$ & $7.49 \pm 0.05^{\mathrm{ab}}$ \\
\hline D5 $\left(4.0 \mathrm{gkg}^{-1}\right)$ & $5.80 \pm 0.27^{\mathrm{a}}$ & $27.50 \pm 0.50^{\mathrm{a}}$ & $7.61 \pm 0.19^{\mathrm{bcd}}$ \\
\hline D6 $\left(8.0 \mathrm{gkg}^{-1}\right)$ & $5.37 \pm 0.09^{\mathrm{a}}$ & $27.00 \pm 1.00^{\mathrm{a}}$ & $7.72 \pm 0.06^{\mathrm{d}}$ \\
\hline
\end{tabular}

$\mathrm{n}=3$. Different letter within the same row shows significant difference at $\mathrm{p} \leq 0.05$.

$\mathrm{D} 1=$ Group fed $0.0 \mathrm{gkg}^{-1}$ diet, D2 $=$ Group fed $0.5 \mathrm{gkg}^{-1}$ diet, D3= Group fed $1.0 \mathrm{gkg}^{-1}$ diet, D4= Group fed $2.0 \mathrm{gkg}^{-1}$ diet, D5= Group fed $4.0 \mathrm{gkg}^{-1}$ diet, D6= Group fed $8.0 \mathrm{gkg}^{-1}$ diet.

\section{Discussion}

The water quality parameters during this study were within the acceptable range [13]. Significant increase in Mean \pm SD weight gain was observed across all the groups fed with crude extract of Azadirachta indica saponins, with significant differences $(p \leq 0.05)$ observed when compared with the mean values of the control group. It has been reported that some saponins increased the permeability of intestinal mucosal cells in vitro [14], [15] also reported that Quillaja saponin could be used to enhance growth, reduce metabolic rate and suppress reproduction in tilapia.

The results obtained from this study shows that Azadirachta indica saponin could be used to enhance the growth rate of Oreochromis niloticus with a considerable increase in growth at a minimal concentration of the crude extract, thus for efficient and sustainable development of tilapia culture Azadirachta indica saponins could be a possible breakthrough.

\section{References}

[1]. V Jayaprakas, and C. Sambhu, Growth response of white prawn, Penaeus indicus to dietary L-carnitine, Asian Fish. Sci., 9, 1996, 209-219.

[2]. R Riguera, Isolating bioactive compounds from marine organisms, Journal of Marine Biotechnology. 5, 1997, $187-193$.

[3]. K Haralampidis, M Trojanowska, and A. E. Osbourn, Biosynthesis of triterpenoid saponins in plants. Advances in Biochemical Engineering/Biotechnology, 75, 2002, 31-49.

[4]. T.L. Mader, and M.C. Brumm, Effects of feeding Sarsasaponin in cattle as swine diet. Journal of Animal Science, 65, $1987,9-15$.

[5]. C.J. Newbold, S.M. ElHassan, J. Wang, Ortega, M.E. and R.J. Wallace, Influence of foliage from African multipurpose trees on activities of rumen protozoa and bacteria, British Journal of Nutrition, 78, 1997, 237-249.

[6]. M.H. Bokhari, and K.M. Aslam, Neem (Azadirachta indica). A useful tree in Northern Nigeria. Annals of Borno, II, $1985,83-86$. 
[7]. W Reed, J Buchard, A.J. Hopson, J Jenness, and I Yaro, Fish and Fisheries of Northern Nigeria. (Ministry of Agriculture Northern Nigeria 1967).

[8]. I.T. Joshi, J.M. Gee, K Price, C Curl, and G.R. Fenwick, Influence of saponins on gut permeability and active nutrient transport in vitro. Journal of Nutrition, 116, 1996, 2270-2277.

[9]. I.O. Obaroh, and G.C. Achionye-Nzeh, Effects of Crude Extract of Azadirachta indica Leaves at Controlling Prolific Breeding in Oreochromis niloticus (Linnaeus, 1758). Asian journal of Agricultural Research, 5 (5), 2011, 277-282.

[10]. M.E. Wall, C.R. Eddy, M.L. McClennan, and M.E. Klump, Detection and Estimation of steroidal sapogenins in plant tissues. Annals of Chemistry, 24, 1952, 1337-1341.

[11]. K Hostettmann, A Marston, and J.L. Wolfender, Strategy in the search for new Biologically active plant constint. in K. Hostetmann, A. Marston, A. Marston, M. Maillard and M.Hamburger, (Eds.), Phytochemistry of plants used in traditional medicine, (Clarendon Press. Oxford, 1995), 17-45.

[12]. A.O.A.C., Official Methods of Analysis $15^{\text {th }}$ Edition. Association of Official Analytical Chemist, (Virginia, USA, 1990,

[13]. L.G. Ross, Environmental Physiology and Energetics, in M.C.M. Beveridge and B.J. McAndrew (ed.), Tilapia and their biology and exploitation (Kluwer Academic Publishers UK, 2000,) 89-128.

[14]. N.L. Johnston, C.L. Quarles, and D.J. Fagerberg, Broiler performance with DSS 40 Yucca saponin in combination with monersin, Poultry Science, 61, 1982,1052-1054.

[15]. G Francis, H.P.S. Makkar, and K Becker, Antinutritional factors present in plant-derived alternate fish feed ingredients and their effects in fish, Aquaculture, 199, 2001, 197-227. 